\title{
EARNING MANAGEMENT AND THE EFFECT CHARACTERISTICS OF AUDIT COMMITTEE, INDEPENDENT COMMISSIONERS: EVIDENCE FROM INDONESIA
}

\author{
Enny Susilowati Mardjono* \\ National Yunlin University of Science and Technology \\ Yahn-Shir Chen \\ National Yunlin University of Science and Technology
}

\begin{abstract}
This study aimed to investigate the effect of the independent commissioner and of the characteristics of the audit committee (measured by auditor size, independence, expertise, and activities) on the efficient or opportunistic earnings management. In terms of those companies listed on Indonesia Stock Exchange. The sample consists of 186 observations of those manufacturing companies in Indonesia Stock Exchange during the 2013-2018. Using panel regression fixed effect method, independent commissioners are found to have a significant effect on reducing earnings management. Based on The Positive Accounting Theory, the efficient perspective will occur when the compensation contract and internal control system, including monitoring done by the board of commissioners, limit the common view opportunistic manager and motivate the manager to choose the right accounting policy. The effective monitoring conducted by an independent commissioner can reduce agency costs because management prioritizes the best interests of shareholders by maximizing company resources. Furthermore, it was found that audit committee size can reduce earning management. It is due to the wide range of skills possessed by audit committee members to exercise oversight over management. Audit committees with accounting and financial expertise can reduce earnings management. This part of finding indicates that audit committee may tend to uphold conservative as accounting mechanism. Accounting conservatism has an important role to play in restricting opportunistic management behavior
\end{abstract}

Keywords: Independent commissioner; Audit committee characteristics; Earnings management.

Received: 25 April 2019

Accepted: 30 March 2020

\section{INTRODUCTION}

Since the occurrence of many cases of financial reporting manipulation, e.g. the Parmalat in Italy, Enron, and WorldCom in the USA, Benford's law in Taiwan, Indofarma in Indonesia, the effectiveness of corporate governance is increasingly needed. Parmalat's earning manipulation apparently began in 1990 and lasted until 2003. Parmalat eventually became a multinational

\footnotetext{
* Corresponding author: Enny Susilowati Mardjono, School of Accountancy, College of Management, National Yunlin University of Science and Technology, 123 University Road, Section3, 64002, Taiwan. Telephone:+886 5534-2601 ext 5414. Email: ennyyoi@yahoo.co.id
} 
conglomerate, and now it is Italy's largest and leading manufacturing company of dairy products and foods. They inflated revenues by creating fake transactions through a double-billing scheme. They even colluded with bankers, third-party auditors to finance the fraud indefinitely with disguised debt as equity on the balance sheet. (Guan, Lin, \& Fang, 2008), following Benford's law, investigate aggressive earnings manipulation that occurs in Taiwanese firms where management has engaged rounding behavior of income numbers to avoid a technical default of its debt covenant. Chi, Liao, \& Chen (2016) found evidence on earning manipulation that occurs in Chinese firms. According to their findings, the CEOs with political connections tended to engage in significantly higher levels of real earnings management. Real earnings management is more difficult to detect than accrual-based earnings management because stakeholders bear the burden of huge financial losses caused by earnings manipulation practices.

Two main problems thought to be able to drive earnings management are agency conflicts and information asymmetry. Chiu, Chung, \& Hung (2019) have suggested that asymmetric information and agency conflict can be reduced if companies in Taiwan implement voluntary adoption of audit committees. One of the important reasons underlying the phenomenon of earnings management continues to exist is the benefits and their efficient side derived from earnings management. The use of earnings management that prioritizes the interests of the company can be categorized as an efficient perspective. The perspective on earnings management can be derived from efficient contracts grounded the Positive Accounting Theory. The efficient contract can provide stronger flexibility for managers to manage earnings in the contract, especially for those incomplete and rigid.

The view of Scott (2015) is that positive accounting theory has two perspectives. i.e. an efficient perspective and opportunistic perspective. The benefits of earnings management can be obtained when managers do earnings management for the interests of shareholders. This phenomenon occurs when it comes to debt covenant practices and political costs. The efficient perspective occurs when the compensation contract and internal control system, including monitoring by the board of commissioners, not only limits the opportunistic manager but also motivate the manager to choose the right accounting policies. The accounting policy selected is one that can help minimize contract costs and company capital costs. Effective corporate governance can reduce agency costs because management prioritizes the best interest of shareholders by means of maximizing company resources. The results derived from the study conducted by Kwon, Lee, \& $\mathrm{Ki}$ (2014) have shown that agency cost are considered essential to weaken the negative relationship between accounting conservatism and corporate governance. Accounting conservatism have an essential role in restricting opportunistic management behavior (Habbash, Sindezingue, \& Salama, 2013). The perspective of opportunistic behavior on earnings management assumes that managers choose accounting policies and use the information asymmetry between the external and internal parties to maximize the expected utility of their related remuneration (bonus schemes), debt covenants and political costs. As a result, Investors then receives reports of unreliable information. Some scandalous practices of financial manipulation that occurred in Indonesia including the case occurred at PT. Garuda Indonesia in 2015, PT. Indofarma Tbk in 2010. Good corporate governance implementation has been increasingly needed since the economic crisis occurred in Indonesia in 1997, and this gave rise to widespread economic crisis across Asia.

SOX requires at least three directors in audit committee, one financial expert, and an independent director. This is particularly important to not only increase director's independence efforts but also 
increase incentives (DeFond \& Zhang, 2014). In their study, the companies listed on two Chinese stock exchanges in Shanghai and Shenzhen, (Chen \& Zhang, 2014) state that independent commissioners may reduce earnings management. Independent commissioners may act as mediators to cope with disputes among internal managers and oversee management policies. (Wan Mohammad, Wasiuzzaman, \& Nik Salleh, 2016) finds evidence on earning management, and they believe that this is determined by a large number of board members from ethnic majority backgrounds (Chandren, Ahmad, \& Ali, 2015) argue that there is a positive impact on the association CEO duality, the board independence, and board size with the accretive share buyback to meet or beat EPS forecast.

The number of earnings manipulation has raised a concern about corporate governance mechanisms in Indonesia. Some regulations were amended to improve the quality of corporate governance such as changes regulations made by the Financial Services Authority (OJK / formerly Bapepam LK) and PT Indonesia Stock Exchange (IDX). OJK published regulation No. 55/POJK.04/2015 concerning the obligations of public companies to have audit committees and guidelines for establishing audit committee. PT Indonesia stock exchange issued regulation No. KEP 00001/BEI/2014 on Amendment of Regulation No. I-A. Regulations issued by OJK and PT Indonesia Stock Exchange both stipulate that audit committee consists of at least one independent commissioner and two other members from outside the Issuer or the said public company. The potential for the acquisition of minority shareholders' rights can be reduced via the new regulation. The regulation acquires a minimum of $30 \%$ of the number of independent commissioners to serve as independent commissioners. The regulation also states stipulates that the responsibility taken by the audit committees is to assist the Board of Commissioners in carrying out financial report or statements used as oversight functions in order to ensure the quality of financial reporting, the effectiveness of internal controls and good corporate governance.

Dechow and Dichev (2002) indicates that the companies whose CEOs also lead the board of directors are more likely to be subject to the accounting enforcement actions by the SEC for alleged GAAP violations. These studies were conducted for onboard systems. Indonesian corporate law stipulates that a company must follow a two-board system consisting of a board of commissioners and board of directors. However, dominated by majority shareholders, the boards of public companies in Indonesia are not independent of each other (Siregar \& Utama, 2008). Contrary to the previous research, (Shahzad, Rauf, ur Rehman, Saeed, \& Al Barghouthi, 2017) have illustrates families as the majority of shareholders, and they have concluded that leverage on real and accrual earnings management has a powerful influence on business. Susanto \& Pradipta (2016) found that expert audit committee in the field of accounting, independent commissioners, and managerial ownership significantly hampered earnings management regarding manufacturing companies listed on IDX.

The audit committee is one of the corporate governance systems that can be used to align the interests of management and majority of shareholders with the minority shareholders. Another study supports this finding, (Lai \& Liu, 2018) also suggest that the audit committee characteristic including size and expertise can reduce earnings management. When a diversified company uses Big $\mathrm{N}$ and experts auditors with a longer tenure, the company has higher quality of financial reports, and so this helps reduce earnings management. Overall, these aforesaid important findings indicate 
that auditor characteristics are important for investors interested in diversified companies because the quality of financial reports can increase.

As well-documented in the latest report from the Corporate Governance Report Watch (CLSA, 2016), Indonesia has weak corporate governance. Indonesia market ranks on the bottom on terms of the Asia-Pacific markets rates. Since the economic crisis occurred in Indonesia in 1997, many cases of financial manipulation have been reported such as Enron Corporation and the dismissal of Andersen. Clearly one thing concerns us greatly is whether monitoring the audit committee and independent commissioners can guarantee earnings management reduction. Therefore, it is interesting to examine relation audit committee, independent commissioners and earnings management from the perspectives on Positive Accounting Theory (two perspectives - the efficient one and opportunistic perspective one).

\section{LITERATURE REVIEW}

\subsection{Previous literature and Hypotheses}

\subsubsection{Association of Independent Commissioner with Earnings Management}

Independent commissioners are members of the board of commissioners who are not affiliated with the board of directors, other commissioners, and controlling shareholders. Besides they are free from business relations or other relationships because this can affect their ability to act independently or to act solely for the interests of the company (OJK, 2015). Independent commissioners do not have direct or indirect shares in the company.

Agency Theory refers to a principal-agent relationship described in a contract (Anthony \& Govindarajan, 2016). In this case, the principal as an independent commissioner plays a decisive role in supervising management policies enacted for a company. In this case, managers as the agents involved in preparing financial statements can obtain quality profits. The Financial Services Authority Regulation (OJK) Number 55/ POJK04/ 2015 clearly state that independent commissioners refer to members of the board of commissioners from outside the issuer or public company. It stipulates that independent commissioners can act as mediators in the disputes among internal managers and so oversee management policies. Scott (2015) argues that the Positive Accounting Theory has an efficient perspective in this regard. The benefits of earnings management can be obtained when managers do earnings management solely for the interests of shareholders. The efficient perspective occurs when the compensation contract and internal control system, including monitoring by the board of commissioners, can limit the opportunistic manager also motivate manager to choose the right accounting policy. The right accounting policy is one thought to be able to possibly minimize contract costs and capital costs. Effective corporate governance can reduce agency costs because management prioritizes the best interest of shareholders by means of maximizing company resources. Through its role in carrying out supervisory functions, the independent commissioners can suppress earnings management and have a definite influence on this. These findings corroborate those derived from the studies conducted by Chen \& Zhang, (2014), Susanto \& Pradipta (2016), and Shahzad et al. (2017). H1: Independent commissioners affect earnings management. 


\subsubsection{Association of Audit Committee with Earnings Management}

Audit committee in the Financial Services Authorization Regulation (OJK) No.55/POJK04/ 2015 is a committee responsible to the board of commissioners and gives assistance in the duties and functions of the board of commissioners. The audit committee must supervise managers to better prepare financial statements. Through the supervisory mechanism governed by the audit committee, it is expected that managers can not to commit fraud in preparing financial statements. (Chiu et al., 2019) found that asymmetric information and agency conflict can be reduced if companies implement voluntary adoption of audit committees. According to (Chen et al., 2008);(Susanto \& Pradipta, 2016);(Xie, Davidson, \& DaDalt, 2003), audit committee has a major effect on earnings management. In Hypothesis 2, characteristics of audit committee with the dimensions of size, independence, expertise, and activities of auditors affect earnings management.

H2: Audit committee affect earnings management.

A large number of audit committees can participate in the corporate governance process and use more financial control and reporting as a whole. (Wan Mohammad et al., 2016);(Badolato, Donelson, \& Ege, 2014);(Lai \& Liu, 2018) found that the effectiveness of audit committee size related to the number of audit committees can reduce earning management. It is due to the wide range of skills of audit committee members can exercise oversight over earnings management. The hypothesis is as follows:

$\mathrm{H} 2_{1}$ : Size audit committee effect earning management

Audit committee is an extension of the board of commissioners to carry out the task of monitoring financial statements and accounting policies carried by management. In order to carry out its duties professionally, audit committee must rather be independent. Based on the empirical evidence from Klein (2002) and Xie et al.(2003), committee audit independence has an impact to accrual policies. The hypothesis posed in this study is illustrated as follows:

$\mathrm{H} 2_{2}$ : Independence audit committee effect earning management

In carrying out the duties of audit committee, expertise in accounting is required so that the task as audit committee can be productive. The audit committee can be more professional in monitoring the process of preparing financial statements by management if the audit committee has expertise in accounting and finance. From the efficient perspective, audit committees with expertise in accounting can reduce opportunistic earnings. Audit committee expertise tend to uphold conservative accounting principles. Accounting conservatism has important role to play in restricting management opportunistic behaviors (Habbash et al., 2013). The previous studies by (Dhaliwal, Naiker, \& Navissi, 2010) ; (Hoitash, Hoita \& Bedard, 2009); (Klein, 2002); (Xie et al., 2003) lend support to this because audit committee members with accounting experience could reduce earnings management. The hypothesis is illustrated as follows:

$\mathrm{H}_{2}$ : Expert audit committee effect earning management 
When the activities are carried out by audit committee as often as possible, they are expected to monitor the process of preparing a good financial statement. In doing so, the quality of financial statements is good. The research conducted by (Xie et al., 2003) shows a relationship between audit activity meeting and the earnings management. Concerning the statements above, the hypothesis is posed as follows:

$\mathrm{H} 2_{4}$ : Activities audit committee effect earning management

\subsection{Variable Definitions and Sample Selection}

\subsubsection{Definition of Earnings management:}

Scholars regard earnings management as the impact of the manager's freedom to choose certain accounting methods when they are about to prepare financial. The dependent variable is earnings management. Earnings management is a condition in which management intervenes in the process of preparing financial statements for external parties to raise and lower the levels of the income statement. (Dechow \& Dichev, 2002) have suggested that the modified Jones model can better detect earnings management, when compared to other models. The starting point for measuring discretionary accruals is to calculate total accruals, which can be divided into two parts: discretionary and nondiscretionary accruals. Nondiscretionary accruals are the accrual components out of the manager's policies, while, in contrast, discretionary accruals are the accrual components influenced by the manager's policies. The measurement model for the accruals in this study can be explained by the following steps (Dechow \& Dichev, 2002) :

TAit $=$ Nit - CFO it

The OLS regression equation estimates the total accrual (TA) value:

TAit / Ait-1 $=\beta 1(1 /$ Ait-1) $+\beta 2(\Delta \mathrm{REVt} /$ Ait-1 $)+\beta 3($ PPEt / Ait-1 $)+\mathrm{e}$.

Using the regression coefficient above, the nondiscretionary accruals (NDA) can be calculated using the formula:

$\mathrm{NDA}=\beta 1(1 /$ Ait-1 $)+\beta 2(\triangle \mathrm{REVt} /$ Ait-1 - $\triangle \mathrm{RECt} /$ Ait-1 $)+\beta 3($ PPEt $/$ Ait-1) $\ldots . . .(3)$

Furthermore, the discretionary accrual (DA) can be calculated as follows:

DAit $=$ TAit $/$ Ait $-1-$ NDA

Information:

DAit $=$ Discretionary Accruals of firm $\mathrm{i}$ in period $\mathrm{t}, \mathrm{NDA}$ it $=$ Non-Discretionary Accruals of firm $\mathrm{i}$ in period $\mathrm{t}, \mathrm{TAit}=$ Total Accrual of firm $\mathrm{i}$ in period $\mathrm{t}, \mathrm{Nit}=$ Net profit of company $\mathrm{i}$ in period $\mathrm{t}$, CFOit $=$ Cash flows from company's operating activities i in period $t$, Ait $-1=$ Total assets of firm $\mathrm{i}$ in period $\mathrm{t}, \Delta \mathrm{REVt}=$ Change of company earnings $\mathrm{i}$ in period $\mathrm{t}, \mathrm{PPEt}=$ fixed asset of company $\mathrm{i}$ in period $\mathrm{t}, \triangle \mathrm{RECt}=$ Change of receivables of company $\mathrm{i}$ in period $\mathrm{t}, \mathrm{e}=$ Error 


\subsubsection{Definition of Independent Commissioner}

Independent commissioners are members of board of commissioners who are not affiliated with board of directors, other commissioners, and controlling shareholders, and they are free from other relationships because this can affect their ability to act independently for the interests of the company (OJK, 2015). The formula by (Klein, 2002) is as follows:

Independent Commissioner $=($ Number of independent commissioners $)$

(Number of all members of the board of commissioners)

\section{Audit Committee}

The audit committee consists of a board of commissioners charged with auditing and supervision of the financial reporting process and internal controls. Audit committee consists of at least one independent commissioner and two other members from outside the Issuer or the said public company (OJK, 2015). Audit committee members are at least three members, and the majority must be independent

\subsubsection{Definition of Characteristics of the Audit Committee}

According to (DeZoort, Hermanson, Archambeault, \& Reed, 2002), the characteristics of the audit committee can be defined as an effective audit committee if the committee has the characteristics of an independent audit for the financial management, internal control, and risk management through diligent supervision efforts. The dimensions of audit committee characteristics include size of audit committee, independence of audit committee, expertise of audit committee in accounting or financial, and activity of audit committee. The operational definition and measurement of each variable can be explained below:

\section{Size of the Audit Committee}

In this study, this variable is measured using the approach used by Badolato et al., (2014) and DeZoort et al. (2002).This approach helps to calculate the number of personnel current audit committee members possessed with the wide range of skills needed for them to exercise oversight over management.

\section{Independence of Audit Committee}

This variable shows the independence level of the audit committee with the company's board of directors. Audit committee independence is the percentage of audit committee members who are non-executive directors without the transactions of relevant parties to the company (Lee \& Mande, 2015)

\section{Audit Committee Expertise}

Several scholars (Krishnan, 2005) (Zhang, Zhou, \& Zhou, 2007) have measured this variable by calculating audit committee members whose expertise is in accounting and finance. (Coates, 
Marais, \& Weil, 2007) used the ordinal scales from 4 to 1 to measure the expertise of audit committee membership. They are describe as follows: scale 4 means that the audit committee has the experience as a controller and accountant; scale 3 means that the audit committee has the experience as a finance director or an expert in finance; scale 2 means that the audit committee has the experience as a manager out of the financial sector; and scale 1 means that the audit committee is an expert out of business field. The scores are measured by calculating the number of audit committees in each corresponding score and then divided by the number of audit committees. Data on the audit committee's expertise is obtained from the sample of a public company's annual report. AC Expertise is measured as the percentage of committee members who have finance or accounting qualification(Lee \& Mande, 2015).

The expertise of the audit committee $=$ Summation of the audit committee per score Summation of the audit committee

\section{Activities of the Audit Committee}

This variable is measured using an approach suggested by (Lee \& Mande, 2015). The calculation are made considering the frequency of the meetings with the board of commissioners and external auditors in one year. It is measured on a scale of intervals from 1 to 7 with the dimensions of the relationships with external auditors, access to financial reporting and monitoring of compliance with IFRS, the review of the effectiveness internal controls, the relationships with internal auditors and commissioners, directors, total audit committee meetings at least three meetings. After the completion of audit committee activities in relation all dimensions, we give a score of 7 . The number of $\mathrm{AC}$ meeting activities is equal to that of audit committee meetings during the year.

\subsubsection{Control Variable}

The four control variables involved in this study are provided as follows:

\section{Revenue Growth}

Revenue growth can trigger companies to modify revenue. Companies generally maintain revenue with rising trends and so produce any increases in profit trends. Therefore, when sales fluctuations occur, companies tend to modify profits. (Kim \& Yoon, 2008) use sales growth as the control variable to observe earnings management. Revenue growth is measured by the ratio of the difference between current and prior period revenues divided by previous period revenue. When revenue growth decreases, management tends to generate earnings management because investors prefer stable or rising revenue growth.

Revenue Growth $=\underline{\text { Revenue } \mathrm{t}-\text { Revenue } \mathrm{t}-1}$

Revenue $\mathrm{t}$

\section{Asset Intensity}

Assets Intensity can be defined as the use of non-current assets in all assets used by a company (Burgstahler \& Dichev, 1997). When asset intensity gets smaller, the use of current assets become more, and the same applies to tendency of management to make earnings management. The companies with higher current assets or current liabilities are more likely to manipulate profits than companies with smaller current assets or current debt do. According to (Burgstahler \& Dichev, 1997), earnings management can be performed by accrual working capital. Companies with current 
assets or current debt are liable to modify profits so as to avoid capitals loss by manipulating working capital.

Intensity assets $=\underline{\text { Non-current assets }}$

Total asset

\section{Debt Structure}

For a company, debt structure is mostly concerned with the amount of source of funds derived from loans. The debt structure is proxied to the proportion of debt held by a company at the date of financial reporting divided by the number of assets held by the company (Mitton, 2002)

Debt structure $=\underline{\text { Total debt of company } \mathrm{i} \text { in period } \mathrm{t}}$

Total assets of the company $\mathrm{i}$ in period $\mathrm{t}$

\section{Company size}

Company size mainly refers to the value of assets owned by a company (Carl \& Thomas, 1999). The amount of assets owned by a company illustrates the number of political costs because the assets of a company concerns stakeholders greatly in terms of the distribution of wealth. Company size $=$ a natural $\log$ of total assets

\subsubsection{Sample Selections}

The data used in this study are the secondary data from the annual report of the manufacturing companies from 2013-2018 in Indonesia Stock Exchange (IDX, 2018). Purposive sampling was undertake to obtain the observation data of 186 companies. The sample selection procedures can be seen in the table below:

Table 1: Sample Selection

\begin{tabular}{lc}
\hline \hline \multicolumn{1}{c}{ Description } & $\begin{array}{c}\text { firm-year } \\
\text { observations }\end{array}$ \\
\hline $\begin{array}{l}\text { Firm-years list on the Indonesia Stock Exchange for the sample period } \\
\text { Less: Firm-years with missing complete data on good corporate governance } \\
\text { mechanism with independent commissioner proxy, and audit committee in the }\end{array}$ & $(82)$ \\
period 2013-2018 & \\
Less: Firm-years with missing present annual financial statements in rupiah & \\
currency units & \\
Manufacturing companies selected to be a sample & 31 \\
Number of Observations & \\
Manufacturing company period 2013-2018 (31 companies x 6 years) & 186 \\
\hline \hline
\end{tabular}

\subsubsection{Research design}


The research aimed to explore whether Independent Commissioner, Audit Committee Characteristics (Audit Committee of Size, Audit Committee of Independence, Audit Committee of Expertise, and Audit Committee of Activity) has explanatory power concerning Earnings Management. The base model presented as follows:

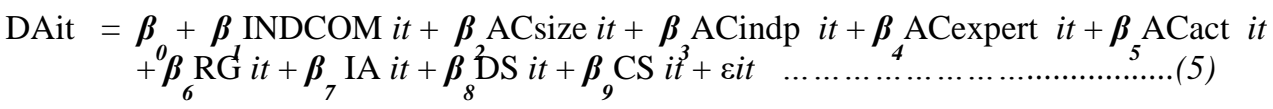

where DAi,t is Discretionary Accruals of firm i in period t (Earnings Management), defined as Total Accrual of firm $i$ in period $t$ divided by Total assets of firm $i$ in period $t$, minus NonDiscretionary Accruals of firm $\mathrm{i}$ in period t. $\beta($ Beta) is coefficient regression (direct connection exogen variable with endogen variable). $A$ is Constanta. $e$ is an error in the formulation is between exogen variable and endogenous variable. INDCOM $i, t$ is an Independent Commissioner i in period $\mathrm{t}$, defined as the percentage of the independent board of commissioners to the total number of existing commissioners in the composition of the board of directors of the sample companies or by the formula (Klein, 2002). ACsize i,t is an Audit Committee of Size $\mathrm{i}$ in period $\mathrm{t}$, defined as calculating the number of the present member audit committee within the company (DeZoort et al., 2002) and (Lee \& Mande, 2015). ACindpi,t is Audit Committee of Independence i in period t, defined as the percentage of audit committee members who are non-executive directors with no related party transactions with the company (Lee \& Mande, 2015). ACexpert i, $t$ is Audit Committee of Expertise $\mathrm{i}$ in period $\mathrm{t}$, defined as the percentage of committee members who are qualified for accounting or finance profession (Lee \& Mande, 2015). ACact i,t is Audit Committee of Activity i in period $\mathrm{t}$, defined as the number of audit committees meetings during the year (Lee \& Mande, 2015). $\varepsilon i, t$ is an Error. Several variables control are Revenue Growth (RG), Intensity of Asset (IA), Debt Structure (DS), and Company size (CS).

\section{METHODOLOGY}

\subsection{Evaluating of Data}

This research uses panel data. Panel data is a combination of time series and cross-sectional data. The regression model can be run with the Eviews. Ghozali \& Ratmono (2018) state that Eviews regarded as a program uses three methods, namely the Common Effect Model (CEM), Fixed Effect Model (FEM) and Random Effect Model (REM). We employed panel data regression to estimated and determine the most appropriate technique to be performed. Firstly, the Chow test is used to choose the best model between the Common Effect Model and Fixed Effect Model. Secondly, the Hausman was used to choose the best model between the Fixed Effect Model and the Random Effect Model. For testing data, Eviews 8 software was used to do so. 


\section{RESULT AND DISCUSSION}

\subsection{Descriptive Statistics}

Table 2 displays the descriptive statistics related to the full sample. The variables seem to be consistent with the existing literature. The mean and median of the earnings are -0.20 and -0.39 respectively.

Table 2: Descriptive Statistics

\begin{tabular}{lcccc}
\hline \hline \multicolumn{1}{c}{ Variable } & Minimum & Maximum & Mean & Std. Deviation \\
\hline IND_COM & 0.250 & 0.500 & 0.377 & 0.072 \\
DAC & -0.096 & 0.718 & 0.205 & 0.168 \\
AC_SIZE & 0.000 & 4.000 & 2.990 & 0.375 \\
AC_INDP & 1.000 & 5.000 & 2.650 & 0.847 \\
AC_EXPRT & 1.000 & 4.000 & 3.010 & 0.653 \\
AC_ACTY & 1.000 & 17.000 & 3.610 & 3.360 \\
REV_GROW & -5.753 & 36.821 & 0.687 & 3.919 \\
INT_ASSET & 0.150 & 0.950 & 0.506 & 0.190 \\
COM_SIZE & 11.146 & 39.350 & 20.323 & 8.453 \\
DEBT_STRUC & 0.001 & 2.340 & 0.531 & 0.352 \\
\hline \hline
\end{tabular}

\subsection{Model Analysis and Hypotheses}

\subsubsection{Selection of Estimated Models}

Through Eviews program, several tests are conducted, namely the CEM test, FEM test, and REM test. The Chow test is then performed to determine the best estimation method between the FEM and CEM models. The best model is determined by looking at the lowest F probability value in the FEM output. Table 3 shows the F probability value of 0.0000 less than $\alpha(5 \%)$, so the best estimation temporary model is the FEM

Table 3: The Chow Test

\begin{tabular}{cccc}
\hline \hline Effects Test & Statistic & d.f. & Prob. \\
\hline Cross-section F & 16.103 & $(30.146)$ & 0.000 \\
Cross-section Chi-square & 271.687 & 30.000 & 0.000 \\
\hline \hline
\end{tabular}

Source: Primary Data that has been processed by Eviews 8 (2018)

As can be seen from Table 3 , the probability value is 0.000 , then the Prob F value is $<0.05$. So it can be concluded that the best model is FEM. Because the Chow Test rejected the CEM model, 
the Hausman Test is selected and performed to determine the best estimate between the REM and FEM models. $\mathrm{HO}=$ the model use REM, while $\mathrm{HI}=$ the model use FEM. If the value of probability F> 0.05 then the best model is REM, If the value of Prob F $<0.05$ then the best model is FEM. The Hausman test results as shows in Table 4. It show the probability value <chi-square $=0.0107$ and smaller than $\alpha(5 \%)$ so H1 (FEM) is accepted and the best estimation model is the FEM model. From the output, it can be seen that the probability value is 0.0107 , then the Prob $\mathrm{F}$ value $<0.05$, the best model is FEM.

Table 4: Hausman Test

\begin{tabular}{cccc}
\hline \hline Test Summary & Chi-Sq. Statistic & Chi-Sq. d.f. & Prob. \\
\hline Cross-section random & 21.471 & 9 & 0.011 \\
\hline \hline
\end{tabular}

Source: Primary Data that has been processed by Eviews 8 (2018)

Based on the test results, FEM is chosen as the best model to estimate the Impact of the Characteristics of audit committee and independent commissioners on earning management.

Table 5: Result of Estimation FEM

\begin{tabular}{ccccc}
\hline \hline Variable & Coefficient & Std. Error & t-Statistic & Prob. \\
\hline C & 0.124 & 0.108 & 1.149 & 0.252 \\
AC_ACTY & 0.002 & 0.002 & 0.818 & 0.415 \\
AC_EXPRT & -0.016 & 0.013 & -1.243 & 0.046 \\
AC_INDP & 0.012 & 0.011 & 1.077 & 0.283 \\
AC_SIZE & -0.039 & 0.021 & -1.834 & 0.069 \\
COM_SIZE & 0.002 & 0.001 & 1.988 & 0.049 \\
DEBT_STRUC & -0.014 & 0.022 & -0.604 & 0.547 \\
IND_COM & -0.354 & 0.170 & -2.083 & 0.039 \\
INT_ASSET & -0.053 & 0.041 & -1.300 & 0.196 \\
REV_GROW & 0.001 & 0.002 & 0.541 & 0.589 \\
\hline R-squared & 0.788 & Mean dependent var & 0.205 \\
Adjusted R-squared & 0.731 & S.D. dependent var & 0.168 \\
S.E. of regression & 0.087 & Akaike info criterion & -1.854 \\
Sum squared resid & 1.109 & Schwarz criterion & -1.160 \\
Log likelihood & 212.422 & Hannan-Quinn criter. & -1.573 \\
F-statistic & 13.922 & Durbin-Watson stat & 1.859 \\
Prob(F-statistic) & 0.000 & & \\
\hline \hline
\end{tabular}

Source: Primary Data that has been processed by Eviews 8 (2018)

Table 5 shows the estimation results of FEM model. There are three significant variables shown with a probability level of $t$ less than 0.05 . To be specific, variables partially affected DAC at a significance level of $5 \%$ and one variable was shown to be significant with t less than 0.10 . F test results shows that the model is significant with an error rate close to $0 \%$. Furthermore, the model shows a coefficient of determination of $78,80 \%$. 


\subsubsection{Classic Assumption Test}

Multicollinearity Test

Table 6: Multicollinearity

\begin{tabular}{lccccccccc}
\hline \hline \multicolumn{1}{c}{ Variable } & $\begin{array}{c}\text { AC_ } \\
\text { ACTY }\end{array}$ & $\begin{array}{c}\text { AC_- } \\
\text { EXPR }\end{array}$ & $\begin{array}{c}\text { AC_ } \\
\text { INDP }\end{array}$ & $\begin{array}{c}\text { AC_ } \\
\text { SIZE }\end{array}$ & $\begin{array}{c}\text { COM_ } \\
\text { SIZE }\end{array}$ & $\begin{array}{c}\text { DEBT_ } \\
\text { STRUC }\end{array}$ & $\begin{array}{c}\text { IND_ } \\
\text { COM }\end{array}$ & $\begin{array}{c}\text { INT_ } \\
\text { ASSET }\end{array}$ & $\begin{array}{c}\text { REV } \\
\text { GRW }\end{array}$ \\
\hline C_ACTY & 1.000 & 0.053 & 0.118 & -0.059 & 0.220 & 0.032 & -0.111 & -0.115 & -0.020 \\
AC_EXPRT & 0.053 & 1.000 & -0.104 & 0.001 & -0.287 & -0.079 & 0.005 & -0.008 & 0.142 \\
AC_INDP & 0.118 & -0.104 & 1.000 & 0.073 & 0.444 & 0.190 & -0.222 & 0.114 & -0.028 \\
AC_SIZE & -0.059 & 0.001 & 0.073 & 1.000 & 0.038 & 0.006 & 0.184 & -0.155 & 0.008 \\
COM_SIZE & 0.220 & -0.287 & 0.444 & 0.038 & 1.000 & 0.225 & -0.130 & -0.080 & -0.171 \\
DEBT_STRUC & 0.032 & -0.079 & 0.190 & 0.006 & 0.225 & 1.000 & -0.081 & 0.129 & 0.010 \\
IND_COM & -0.111 & 0.005 & -0.222 & 0.184 & -0.130 & -0.080 & 1.000 & -0.135 & 0.005 \\
INT_ASSET & -0.115 & -0.008 & 0.114 & -0.155 & -0.080 & 0.129 & -0.135 & 1.000 & 0.024 \\
REV_GROW & -0.020 & 0.142 & -0.028 & 0.008 & -0.171 & 0.010 & 0.005 & 0.024 & 1.000 \\
\hline \hline
\end{tabular}

Source: Primary Data that has been processed by Eviews 8 (2018)

From the output, the correlation value between independent variables is observed to be less than 0.8 . Thus, It can be concluded that the model is free of multicollinearity

\section{Heteroscedasticity Test}

Table 7: Heteroscedasticity

\begin{tabular}{ccccc}
\hline \multicolumn{1}{c}{ Variable } & Coefficient & Std. Error & t-Statistic & Prob. \\
C & 0.014 & 0.080 & 0.173 & 0.863 \\
AC_ACTY & -0.001 & 0.001 & -1.265 & 0.208 \\
AC_EXPRT & 0.005 & 0.006 & 0.852 & 0.396 \\
AC_INDP & 0.011 & 0.007 & 1.515 & 0.132 \\
AC_SIZE & 0.008 & 0.021 & 0.398 & 0.691 \\
COM_SIZE & -0.000 & 0.001 & -0.202 & 0.840 \\
DEBT_STRUC & -0.005 & 0.017 & -0.315 & 0.753 \\
IND_COM & -0.041 & 0.119 & -0.349 & 0.728 \\
INT_ASSET & -0.005 & 0.025 & -0.188 & 0.851 \\
REV_GROW & -0.000 & 0.001 & -0.768 & 0.444 \\
\hline R-squared & 0.366 & Mean dependent var & 0.054 \\
Adjusted R-squared & 0.196 & S.D. dependent var & 0.055 \\
S.E. of regression & 0.049 & Akaike info criterion & -2.994 \\
Sum squared resid & 0.355 & Schwarz criterion & -2.301 \\
Log likelihood & 318.463 & Hannan-Quinn criter. & -2.713 \\
F-statistic & 2.157 & Durbin-Watson stat & 2.986 \\
Prob (F-statistic) & 0.001 & & \\
\hline \hline
\end{tabular}

Source: Primary Data that has been processed by Eviews 8 ( 2018) 
From the t-test output, the probability value $t$ indicates that all independent variables are higher than 0.05 ; the model is free from heteroscedasticity.

\subsection{3. $\quad$ F Test, T-Test (Hypothesis), Determination Coefficient.}

\section{F Test - Statistics}

Table 8: F test - statistic

\begin{tabular}{ll}
\hline \hline Number of Observations & $\mathbf{1 8 9}$ \\
\hline F-statistic & 13.922 \\
\hline Prob $>$ F & 0.000 \\
\hline \hline
\end{tabular}

As shown in Table 5, F-statistical probability value of 0.000 is obtained, which is smaller than the value of $\alpha=5 \%$. F value of 13,922 with a significance of 0,000 means that simultaneously all independent variables can explain the dependent variable, or that the model used to do so is appropriate. R Square value of 0.788 means that the DAC is explained by the nine independent variables at $78.8 \%$ while the remaining $21.2 \%$ is explained by other variables excluded from the model.

\section{T-Test - Statistics}

The t-test is usually performed to test hypotheses about the coefficients of slope regression individually using the Fixed Effect Model (FEM) method.

Table 9: Test $\mathrm{t}$ - Statistics

\begin{tabular}{ccccc}
\hline \hline Variable & Coefficient & Std. Error & t-Statistic & Prob. \\
\hline C & 0.124 & 0.108 & 1.149 & 0.252 \\
AC_ACTY & 0.002 & 0.002 & 0.818 & 0.415 \\
AC_EXPRT & -0.016 & 0.013 & -1.243 & 0.046 \\
AC_INDP & 0.012 & 0.011 & 1.077 & 0.283 \\
AC_SIZE & -0.039 & 0.021 & -1.834 & 0.069 \\
COM_SIZE & 0.002 & 0.001 & 1.988 & 0.049 \\
DEBT_STRUC & -0.014 & 0.022 & -0.604 & 0.547 \\
IND_COM & -0.354 & 0.170 & -2.083 & 0.039 \\
INT_ASSET & -0.053 & 0.041 & -1.300 & 0.196 \\
REV_GROW & 0.001 & 0.002 & 0.541 & 0.589 \\
\hline \hline
\end{tabular}

Source: Primary Data that has been processed by Eviews 8 (2018)

Table 9 displays the panel data regression using the Fixed Effect Model (FEM). The results indicate that the probability of $t$ on variables AC_EXPRT, COM_SIZE, and IND_COM is less than 0.05, so it can be concluded that the variable partially influences the DAC at the 5\% significance level. The AC_SIZE variable partially affects DAC at a significance level of $10 \%$. As expected, DAC is proved to be negatively correlated with AC_SIZE, AC_EXPR, and IND_COM at statistically significant level. From the tabulated results, the independent commissioner has a 
significant effect on the decrease in earnings management. Independent commissioner is expected to represent the interests of the minority of shareholders because they have no conflict of interest with the company. Thus, take financial reporting as a real example, the activities carried out by management do not always give benefits to the shareholders and stakeholders. In order for financial reporting to be in accordance with the interests of various parties, it is necessary to be controlled and performed by an independent commissioner.

This study proved that the monitoring conducted by an independent commissioner can reduce earnings management. The main reason for this are as follows. The first requirement of an independent commissioner in accordance with the regulation of OJK No. 55 /POJK.04/2015. The regulation stipulates that audit committee consists of at least one independent commissioner and two other members from outside the issuer or public company. To reduce the potential for the acquisition of minority shareholders' rights (ie, public shareholders), the regulation requires that the minimum percentage of the number of independent commissioners should be $30 \%$, and they serve as independent commissioners. The benefits of earnings management can be obtained when managers do earnings management for the interests of shareholders. This phenomenon occurs in not only debt covenant practices but also political costs. The efficient perspective occur when the compensation contract and internal control system, including monitoring by the board of commissioners, limits the opportunistic manager and motivates manager to choose the right accounting policies. The chosen accounting policy is deemed as one that can help minimize contract costs and company capital costs.

Manipulation of financial statements in large corporations in 2000-2001 prompted the United States government to issue the Sarbanes-Oxley Act on July 30, 2002. This was to reorganize corporate governance. An investigation conducted by Bapepam-LK found that there were three versions of Lippo Bank's financial statements published on the $30^{\text {th }}$ of September, 2002. Board of directors Lippo was involved in earnings management practices to cover a loss of 1.277 trillion rupiahs through the allowance for elimination of earning assets. In response to the issuance of SOX, Bapepam-LK issued a regulation regarding the Establishment and Guidelines for the Work of the Audit Committee through Decree of the Chairman of Bapepam-LK Kep-29/PM/2004. The revision regulation states that public companies must have audit committee. Even before the issuance of Bapepam LK 2014, the government has required public companies to form an audit committee and independent commissioner through the Securities Registration Number IA 20 July 2001, the compliance of capital market issuers with this IDX regulation is deficient. In early 2003 there were 331 companies listed on the IDX, only $77 \%$ of the companies that had formed an audit committee and appointed an independent commissioner.

This study proved that independent commissioner is negatively related to earnings management. In this case Bapepam-LK and IDX decree issued in 2004 could be replaced by POJK 2015 regulations, for this has effectively improved performance of board of commissioners in reducing earnings management. Before the issuance of Bapepam-LK and IDX decree in 2004, the independent commissioner has no effective role in enhancing the supervisory function of the board of commissioners. After the issuance of the Bapepam-LK and the POJK regulations was replaced in 2015 in an attempt to centralize the functions and authority of board of commissioners and audit committee. The improvement of the supervisory function is reflected in the negative impact of the 
board of commissioners on earnings management, which was found to be stronger during the period of time when the issuance of the Bapepam-LK and IDX decree in 2004 was replaced by the POJK in 2015. The task of capital market supervision from Bapepam-LK was transferred to the OJK on the $31^{\text {st }}$ of December, 2012 with an aims to have the system of regulation and supervision centralized and integrated into activities within financial services sector in the banking, capital market and non-bank financial services.

Table 9 presents relationship between earnings management and independent commissioners. We obtain negative coefficients -0.353 significant at 0.05 . Hence $\mathrm{H} 1$ is not rejected. Through its role in carrying out supervisory function, the independent commissioners can influence and suppress earnings management so managers in preparing financial statements can obtain quality profits. Consistent with previous study, the independent commissioners significantly reduce earning management (Chen \& Zhang, 2014);(Susanto \& Pradipta, 2016); (Shahzad et al., 2017). The regulator with the corporate governance mechanism can minimize conflict within the opportunistic managers. The independent commissioners can monitor and guide managers to choose the right accounting policies through a closer inspection of the truth of the materials of both the governance structures and processes.

As can be seen from Table 9, the coefficients on the interaction size of audit committee with earnings management is negative with a value of 0.0392 at the significant level of 0.10 . In this case $\mathrm{H} 2_{1}$ is supported. Through the supervisory function carried out by audit committee, it is expected to urge managers not to commit fraud in the preparing financial statements. A large number of audit committees will participate in the corporate governance process and control financial reports as a whole. (Badolato et al., 2014);(Lai \& Liu, 2018) found the effectiveness of audit committee size is related to the number of audit committees can reduce earning management. It is due to the full range of skills exerted by audit committee members to exercise oversight over management.

Table 9 shows the association between independent audit committee and earnings management. The coefficients are positive with a value of 0.012 ; thus, it is insignificant and $\mathrm{H} 2_{2}$ are not supported. This represents that appointment of audit committee has independence characteristics just only to comply with prevailing regulation.

This study lists the regression results of the audit committee expertise associated with the impact on earnings management. This part of the results support $\mathrm{H} 2_{3}$. On average, at the time of the survey, the sample of companies have audit committees with accounting backgrounds so they could work as expected. Regarding the negative effect of audit committee expertise measured as 0.016 , this finding indicates that audit committee can tend to uphold conservative as accounting mechanism. Accounting conservatism has an essential role to play in restricting opportunistic management behaviors (Habbash et al., 2013). The Positive Accounting Theory has an efficient perspective; audit committees with expertise in accounting and finance can therefore reduce opportunistic earnings management. When a company has a debt structure, the audit committee uses its expertise in accounting to control the size of debt structure that is not too high. With this in mind, the company is not trapped in a violation of the debt covenant, which, in turn, leads to increased earnings management practices. (Dhaliwal et al., 2010); (Klein, 2002) support this study because they found evidence that audit committee with accounting experience impact negative on aggressive earnings management. 
Table 9 shows the result of the audit committee activities. We obtain coefficients 0.0019 insignificant. Thus $\mathrm{H}_{2}$ is not supported, and this part of the results is consistent with that reported in previous studies (Kim \& Yoon, 2008). The meetings carried out by audit committee have not been able to work effectively so the purposes of audit committee formation have not proceeded as expected. OJK is still not optimal in checking the truth implementation of corporate governance description in its annual report about audit committee activities.

\section{CONCLUSION}

This paper helped to raise awareness of earnings management, and has produced several significant implications First, monitoring by independent commissioner will limit the opportunistic managers and so motivate managers to choose the right accounting policy. Management is more likely to choose efficient earnings management, when compared to opportunistic behavior. The efficient perspective can occur when the compensation contract and internal control system minimize contract costs and capital costs. The benefits of earnings management can be obtained when managers do earnings management for the interests of shareholders. This study prove that the monitoring conducted by independent commissioners can reduce earnings management and restrict opportunistic management behavior.

Second, it find that independent commissioners, audit committee size and audit committee expertise show the effective reduction of corporate governance practices in earnings management. The requirement of an independent commissioner with the regulation of OJK No. 55 /POJK.04/2015 can reduce earnings management. The regulation stipulates that an audit committee consists of at least one independent commissioner and two other members from outside the issuer or the said public company. The rights to the acquisition of minority shareholders can be affected because the application of regulation requires a minimum of $30 \%$ of independent commissioners.

Third, audit committee size related to the number of audit committees can constrain opportunistic earnings management. This is due to the wide range of skills possessed by audit committee members to exercise oversight over management. This finding indicates that audit committee can tend to uphold conservative as corporate mechanism. Accounting conservatism has an essential role to play in restricting opportunistic management behaviors. From the perspective of efficient management, audit committees with expertise in accounting and finance can better reduce opportunistic earnings management.

\section{REFERENCES}

Anthony, R. N., \& Govindarajan, V. (2016). Management Control Systems (12 $2^{\text {th }}$ ed). Boston: Mc Grraw-Hill.

Badolato, P. G., Donelson, D. C., \& Ege, M. (2014). Audit committee financial expertise and earnings management: The role of status. Journal of Accounting and Economics, 58(2-3), 208-230. https://doi.org/10.1016/j.jacceco.2014.08.006 
Burgstahler, D., \& Dichev, I. (1997). Earnings management to avoid earnings decreases and losses. Journal of Accounting and Economics, 24(1), 99-126. https://doi.org/10.1016/S0165-4101(97)00017-7

Carl R. C., \& Thomas L. S. (1999). Managerial ownership and agency conflicts: Nonlinear simultaneous equation analysis of managerial ownership, risk taking, debt policy, and dividend policy. The Financial Review, 34(2), 119-136. https://doi.org/10.1086/250095

Chandren, S., Ahmad, Z., \& Ali, R. (2015). Corporate governance mechanisms and accretive share buyback to meet or beat earnings per share forecast. International Journal of Business and Society, 16(3), 344-363.

Chen, J. J., \& Zhang, H. (2014). The impact of the corporate governance code on earnings management - Evidence from Chinese listed companies. European Financial Management, 20(3), 596-632. https://doi.org/10.1111/j.1468-036X.2012.00648.x

Chi, J., Liao, J., \& Chen, X. (2016). Politically connected CEOs and earnings management: Evidence from China. Journal of the Asia Pacific Economy, 21(3), 397-417. https://doi.org/10.1080/13547860.2016.1176644

Chiu, J., Chung, H., \& Hung, S. C. (2019). Voluntary adoption of audit committees, ownership structure and firm performance: Evidence from Taiwan. Emerging Markets Finance and Trade, 1-29. https://doi.org/10.1080/1540496x.2019.1635449

CLSA. (2016). CG watch 2016. Retrieved from https://www.clsa.com/media-release-cg-watch

Coates, D. J., Marais, M. L., \& Weil, R. L. (2007). Audit committee financial literacy: A work in progress. Journal of Accounting, Auditing \& Finance, 22(2), 175-194. https://doi.org/10.1177/0148558X0702200207

Dechow, P. M., \& Dichev, I. D. (2002). The quality of accruals and earnings: The role of accrual estimation errors. The Accounting Review , 77, 35-59.

DeFond, M., \& Zhang, J. (2014). A review of archival auditing research. Journal of Accounting and Economics, 58(2-3), 275-326. https://doi.org/10.1016/j.jacceco.2014.09.002

DeZoort, F. T., Hermanson, D. R., Archambeault, D. S., \& Reed, S. A. (2002). Audit committee effectiveness: A synthesis of the empirical audit committee literature. Journal of Accounting Literature, 21, 38-75. https://doi.org/10.22495/cbv8i1art2

Dhaliwal, D., Naiker, V., \& Navissi, F. (2010). The association between accruals quality and the characteristics of accounting experts and mix of expertise on audit committees. Contemporary Accounting Research, 787-827. https://doi.org/10.1111/j.1911-3846.2010.01027.x

Ghozali, I., \& Ratmono, D. (2018). Analisis Multivariate dan Ekonometrika: Teori, consep dan aplikasi dengan menggunakan EViews 8. Semarang: Diponegoro University Publishing Agency.

Guan, L., Lin, F., \& Fang, W. (2008). Goal-oriented earnings management: Evidence from Taiwanese firms. Emerging Markets Finance and Trade , 44(4), 19-32. http://www.tandfonline.com/loi/mree20 Goal-Oriented.

Habbash, M., Sindezingue, C., \& Salama, A. (2013). The effect of audit committee characteristics on earnings management: Evidence from the United Kingdom. International Journal of Disclosure and Governance, 10, 13-38. https://doi.org/10.1057/jdg.2012.2

Hoitash, U., Hoitash, R., \& Bedard, J. C. (2009). Corporate governance and internal control over financial reporting: A comparison of regulatory regimes. Accounting Review, 84(3), 839867. https://doi.org/10.2308/accr.2009.84.3.839 
IDX. (2018). Indonesia Stock Exchange. Retrieved from http://www.idx.co.id/enus/products/index/

Kim, H. J., \& Yoon, S. S. (2008). The impact of corporate governance on earning management in Korea. Malaysian Accounting Review, 7(1), 43-59.

Klein, A. (2002). Economic determinants of audit committee independence author(s). The Accounting Review, 77(2), 435-452. Retrieved from https://www.jstor.org/stable/pdf/3068905.pdf?refreqid=excelsior\%3Ac105c50553c9e22

Krishnan, J. (2005). Audit committee quality and internal control: An empirical analysis. The Accounting Review, 80(2), 649-675.

Kwon, S. Y., Lee, N. R., \& Ki, E. (2014). Effects of agency costs on the relationship of corporate governance with audit quality and accounting conservatism in the Korean audit market. Asia-Pacific Journal of Accounting and Economics, 21(2), 157-185. https://doi.org/10.1080/16081625.2012.762970

Lai, S. M., \& Liu, C. L. (2018). The effect of auditor characteristics on the value of diversification. Auditing: A Journal of Practice \& Theory, 37(1), 115-137. https://doi.org/10.2308/ajpt-51831

Lee, H. Y., \& Mande, V. (2015). The relationship of audit committee characteristics with endogenously determined audit and non-audit fees. Quarterly Journal of Business and Economics. 44(3-4), 93-105

Mitton, T. (2002). A cross-firm analysis of the impact of corporate governance on the East Asian financial crisis. Journal of Financial Economics, 64(2), 215-241.

OJK. (2015). Otoritas jasa keuangan republik indonesia.

Scott, W. R. (2015). Financial accounting theory ( $7^{\text {th }}$ ed). Canada: Prentice Hall.

Shahzad, F., Rauf, S. A., ur Rehman, I., Saeed, A., \& Al Barghouthi, S. (2017). Earning management strategies of leveraged family and non-family controlled firms: An empirical evidence. International Journal of Business and Society, 18(3), 503-518.

Siregar, S. V., \& Utama, S. (2008). Type of earnings management and the effect of ownership structure, firm size, and corporate-governance practices: Evidence from Indonesia. The International Journal of Accounting, 43(1), https://doi.org/10.1016/J.INTACC.2008.01.001

Susanto, Y. K., \& Pradipta, A. (2016). Corporate governance and real earning management. International Journal of Business, Economics and Law, 9(1), 17-23.

Wan Mohammad, W. M., Wasiuzzaman, S., \& Nik Salleh, N. M. Z. (2016). Board and audit committee effectiveness, ethnic diversification and earnings management: A study of the Malaysian manufacturing sector. Corporate Governance, 16(4), 726-746. https://doi.org/10.1108/CG-06-2015-0085

Xie, B., Davidson, W. N., \& DaDalt, P. J. (2003). Earnings management and corporate governance: the role of the board and the audit committee. Journal of Corporate Finance, 9(3), 295316. https://doi.org/10.1016/S0929-1199(02)00006-8

Zhang, Y., Zhou, J., \& Zhou, N. (2007). Audit committee quality, auditor independence, and internal control weaknesses. Journal of Accounting and Public Policy, 26(3), 300-327. https://doi.org/10.1016/j.jaccpubpol.2007.03.001 